\title{
INDO- AFGHAN RELATIONS: A HISTORICAL ANALYSIS
}

\author{
Aamir Junaid \\ Visiting Lecturer \\ Department of International Relations \\ Government College University \\ Faisalabad - Pakistan. \\ aamirjunaid798@gmail.com \\ Abdul Malik \\ M.phil Political Science \\ Department of Political Science \\ Government College University \\ Faisalabad - Pakistan \\ amalikbaloch@gmail.com \\ Muhammad Ashraf Nadeem \\ M.phil International Relations \\ Department of International Relations \\ Government College University \\ Faisalabad - Pakistan \\ ashrafnadeembaloch@gmail.com
}

\section{Abstract}

India always had cordial ties with Afghanistan except for the four years of the Taliban rule. September 11 replaced the planet's political and security structure and gave India a chance to enter Afghanistan. Afghanistan's strategic position attracts the global community and it is a gateway to energy-rich CARs. New Delhi's interest in Afghanistan is quite realistic. After the end of the Taliban government in 2001, India increased its influence in Kabul, attended the Bonn Conference, and pledged to support Afghan people in the rehabilitation process. New Delhi enjoyed cordial ties with democratically elected regimes in Afghanistan and promoted its relations with Tehran to protect its objectives in Kabul to contain Islamabad. India has infused a lot of money in several projects in Afghanistan to increase its impact in Afghanistan. The global community thinks India is effective advertising in Southern Asia, but Pakistan believes New Dehli's foot in Kabul threatens its security. Islamabad stresses New Delhi must support Afghan nationals and avoid working against Pakistan 


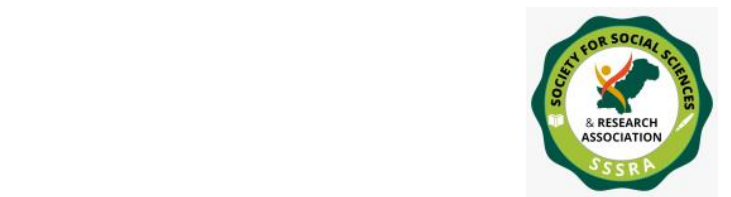

Pak. Journal of Int'L Affairs, Vol 4, Issue 4 (2021)

Indo- Afghan Relations: A Historical ...

from Afghan soil. Afghanistan has been suffering from war for the last two decades. This paper highlights the historical ties between India and Afghanistan.

Keywords India, Afghanistan, Pakistan, World, War, Relations

\section{Introduction}

Afghanistan and India have signed a mutual agreement named the Peshawar treaty back in 1855. India has always enjoyed cordial ties with Kabul after the independence of the Sub-Continent except for the Taliban regime. The incident of 9/11 provided an opportunity for the Indian administration to come physically to Afghanistan. India made several efforts to justify its existence in Afghanistan to play a constructive part in the rehabilitation process. New Dehli's fundamental concern was to overcome the domination of Islamabad in Afghanistan and to use Afghan soil against Pakistan (Rehman, 2014). Afghanistan has always remained a battlefield for outer elements. New Dehli has worked a lot on the ground to change the thinking of Afghan youth against Pakistan; it is why over $70 \%$ of Afghans think New Delhi is a good choice over Islamabad and Washington (Constantino, 2020). However, Islamabad suffered a lot from the destabilization in Afghanistan. India has become the $5^{\text {th }}$ biggest supporter of Afghanistan by pledging over $1.2 \$$ billion since 2001 (Joshi, 2018). Pakistan has expressed severe concerns about the Indian existence in Kabul and RAW's militant activities in the Waziristan region (Saleem, 2018). India wants to destabilize Pakistan and the involvement of RAW in different incidents in Pakistan shows the intentions of India.

China Pakistan Economic Corridor is the game-changer Programme of Pak- China collaboration and is a ray of hope for Pakistan's economy. India, through its puppets in Afghanistan, had made several attempts to sabotage it but failed. (Shah, 2017). India is afraid and does not like the Taliban militants into power in Afghanistan and thinks of the Taliban as a proxy of Pakistan. India likes to remain a crucial partner in Afghanistan, and New Delhi can utilize all connections to stay on the territory of Afghanistan. Islamabad wants a stable Afghanistan, New Delhi and other regional countries; India is afraid of the Taliban and Pakistan nexus (Paliwal, 2015). India constantly desired to become the hegemonic state of South Asia and tried to get support from the global powers to achieve it. India is enhancing its impact through a soft image in Afghanistan to get attention from the world community. New Delhi is also facing internal security issues. The Kashmir issue and conflict with Islamabad are the main barriers to India's rule of South Asia and now focusing on enhancing its security and economic capabilities for a decade. No doubt, India has got a charming advertise for other countries due to its size and people. The 


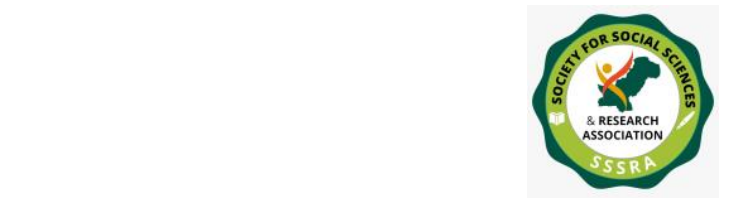

global community considers India an appropriate country for investment. Now New Delhi wants to get the attention of significant powers to enhance its impact through soft image (Pande, 2020). Taliban and US have inked an agreement for peace on February 29, 2020, in Doha. The Taliban are now capturing cities and have entered Kabul and US forces have left Afghanistan. This research paper puts light on Indo-Afghan relations in the context of history.

\section{Research Methodology}

The writer applied a qualitative Method to conclude this work and got support from the existing literature, articles, and books to complete this paper. The author took help from print and electronic media and online materials to write this paper. This paper enables the readers to understand Indo-Afghan relations from the lens of history.

\section{Literature Review}

"Perspective on South Asian Security" by Shanthie D'Souza and Rajshree Jetly. It explains the exciting security condition of the South Asian region. Afghanistan has been a state suffering from war for almost forty years and it is the crucial topic of this book. India's foreign policy to Afghanistan and Kabul's neighbouring state, security is the main agenda. Permanent peace and stability in Afghanistan are necessary for the whole region. It gives great importance to Kabul as New Delhi has infused money in Kabul. This writing puts light on India's foreign policy to Afghanistan (Souza \& Jetly, 2012).

"The New Great Game in Afghanistan: Role of India (A Pakistani Perspective)" drafted by Dr. Iram Khalid. This paper discusses the interest of global powers in Kabul. The writer highlights New Delhi's activities in Kabul after September 11; She also talks about India's investment in Afghanistan. Dr. Iram explained the ambitions of New Delhi in Kabul. Dr. Iram also spoke about the New Dehli's aspirations in the area (Khalid, 2011).

"Indian Strategic Influence in Afghanistan: Realist Ends through Social Means" by Marium Kamal. New Dehli is an essential player in South Asian and global politics. India is focusing on spreading its wings through security and economy. New Dehli's existence in Kabul is increasing its soft image to get its deep-rooted international politics aims. The author described New Dehli's hold on Afghan internal matters and actions in Afghanistan (Kamal, 2019).

"Delhi-Kabul Nexus: Regional Dynamics and Geopolitical Perspective (With Reference to Pakistan)" by Fazal Abbas Awan, Asia Sial Alvi and Rabia Munir. The authors 


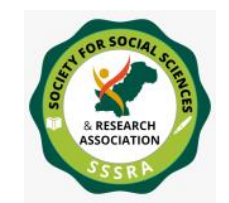

Pak. Journal of Int'L Affairs, Vol 4, Issue 4 (2021)

Indo- Afghan Relations: A Historical ...

stressed New Dehli and Islamabad's role in bringing stability in Southern Asia and elaborated on the Indian role in Kabul and its implications on Pakistan. This paper elaborates New Dehli's security aims, political goals, and economic ambitions in Kabul, India's intentions to reach Central Asian republics via Afghanistan. The authors also explained the US policy to contain China by using India (Awan, Alvi, \& Munir, 2019).

India's Role in Afghan Peace Process by Dr. Ghulam Mustafa, Aamir Junaid, Rana Basam Khan and Imran Wakil. The writers highlight the cunning character of India in Kabul. India has infused a massive amount in Afghanistan in various programs. India is trying to enhance its soft power by pouring money into Afghanistan. New Delhi has clear intentions in Afghanistan to eradicate the influence of Pakistan on Afghan society and India has got success to some extent. India is using Afghan soil against Pakistan. The writers explain the role of India and its intentions in Afghanistan (Mustafa, Junaid, Khan, \& Wakil, 2020).

The writers highlighted Indian aims in Afghanistan and New Delhi tries to achieve a high place in world politics. India does not want to allow Pakistan to play freely in Afghanistan. It is essential to work on India's ties with Kabul.

\section{Indo-Afghan Relations}

The global community is well aware of New Delhi's connections with Kabul after the independence from the British. The deadly incident of September 11 invited India into Afghanistan. It was tested to present New Dehli's existence in Kabul that New Delhi will act as a significant pillar in the rehabilitation process of Afghanistan. Its fundamental goal was to overcome Pakistan's influence in Kabul. New Delhi likes to become the hegemonic state of South Asia and the existence of Islamabad is the main worry for India. New Dehli had positive ties with Afghan regimes except for the Taliban rule. The geography of Afghanistan attracts India to indulge in friendly relations with Kabul. Central Asian republics with an abundance of natural wealth are the leading destination of New Delhi. It increased its commerce ties with Kabul but also worked on several programs. After the USSR attack and later the establishment of the Taliban government, New Delhi was nowhere in Afghanistan. However, India always funded the anti-Taliban forces in Afghanistan (Ahmed \& Bhatnagar, 2015). There was no Indian embassy in Afghan territory during the government of the Taliban. New Dehli got importance in Kabul after the brutality of 9/11. Although India had never sent its troops to Afghanistan. The US dismantled the Taliban rule in 2001, Hamid Karzai took oath as a President. New Dehli considered it an excellent time to get strong grounds in Afghanistan by infusing amount into the rehabilitation process in Afghanistan. India has long traditional linkages 


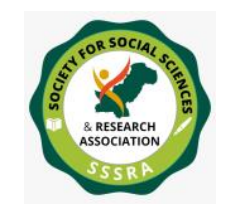

Pak. Journal of Int'L Affairs, Vol 4, Issue 4 (2021)

Indo- Afghan Relations: A Historical ...

with Afghan people and compelled it to support financially and politically for rebuilding the country (D'Souza, 2014). New Delhi's existence in Kabul can be traced in the bigger picture and it is putting effort to increase its impact in South Asia and create hegemony in this part of the world. New Delhi has a bigger market than all other South Asian states, so it's easy for India to set friendly ties with the world community (Fair, 2014). US Assistant Secretary of state for Southern and Central part of Asia pointed out the significance of New Delhi in a meeting in the House of foreign affairs in February 2013. Secretary clearly stated that New Delhi has a central point in the discussion of South Asia. Assistant Secretary also told the members about New Delhi's efforts for Afghanistan (The Hindu, 2013). New Delhi pledged to help Afghanistan by announcing two billion $\$$ at the Tokyo conference held in January 2002 (Price, 2013). New Delhi and Kabul agreed to cooperate in various projects and overcome trust deficits (Price, 2013). New Delhi and Kabul were engaged right after the demise of the Taliban regime at the beginning of 2002. Hamid Karzai and Ashraf Ghani went many times to India during their times in power. India has supported Afghanistan on different occasions and took a keen interest in the rehabilitation process in the state. During the regimes of two democratic elected Presidents, New Delhi could open an embassy in Kabul and worked to open its consulates in several Afghan cities. Afghanistan became a member of (SAARC) due to Indian support. This initiative supported both states to come closer (Kaur, 2017). New Delhi also took various steps to support the masses.

India facilitated Afghans to come and get education from best institutions and get medical facilities; visa policy also changed for students and old persons. India pledged to give Afghan citizens a visa for two years and exempted children and old ones from police verification. It was considered a positive step from the Indian side to increase its contacts with the local Afghans. New Delhi is also playing a crucial part in supporting the economy of Afghanistan and both countries have inked a commerce deal to enhance commerce between both states (Grades Fixer, 2019). Custom duty was reduced and trade between both states will be increased according to the deal. It was a crucial move to support the Afghan economy; as a result, commerce reached a record high of $600 \$$ million in 2013 and is predicted to reach $3 \$$ billion in a few years. It bet on the security condition in Kabul. Peace and stability encourage trade among countries; both states are hopeful of achieving the maximal interest of commerce and like to alter the life style of the commoner (Ahmed \& Bhatnagar, 2015). Afghan soil is rich with natural wealth and New Delhi has inked an agreement on a strategic partnership with Afghanistan. New Delhi wants to remain in Afghanistan relevant and that's why India was taking part in various programs like transport, communications, and IT. Two agreements also inked by India to find out hidden sources (Choi, 2014). Central Asian states are rich with natural wealth and New Delhi tries to access this part of the world. New Delhi wants to get 


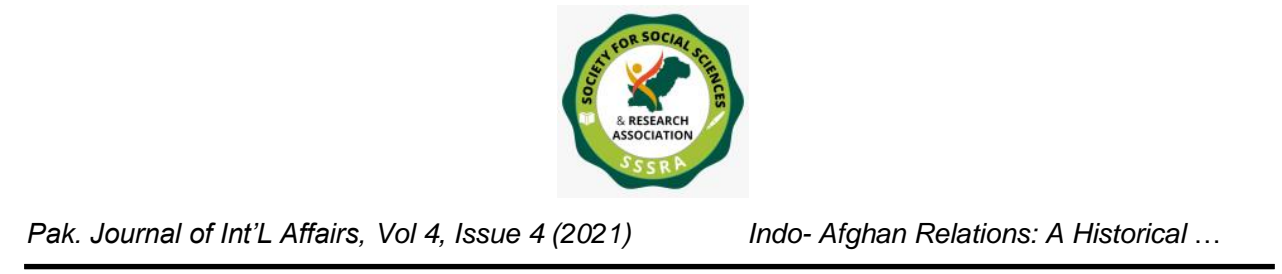

benefits from the untapped natural wealth of Central Asia via Kabul. India can access Central Asian republics, including Russia, via Kabul (Siddiqui, 2017). The entrance of the Taliban into power corridors is a real threat for India. India is well aware that the Taliban has won over NATO and US troops in Kabul and has become Afghanistan's powerful political identity. Foreign aid is the main source of the Afghan economy and states are reluctant to support Afghanistan. Opium is the key crop of Afghanistan and produces almost $80 \%$ of the global opium (Tolo News, 2018). New Delhi puts effort to find new ways to stay relevant in Afghan politics. India's existence in Afghanistan highlights its need to enhance its security to manage the external atmosphere in Kabul. In other words, Kabul has clinched a crucial place in the external affairs outlines of New Delhi (Pant, 2010).

New Delhi has been divided its goals into three categories, regional hegemony to security and economic power. New Delhi often sees Afghanistan from the lens of security. New Delhi and Islamabad both want to remain relevant in internal Afghan politics. India does not want to allow Pakistan to play its cards in Afghanistan freely and on the other hand, Islamabad thinks New Delhi wants to engage it on its western border. New Delhi also sent a small number of its soldiers to protect Indian workers in Afghanistan in the past (Kaul, 2007). India is against the Islamic militancy in Afghanistan and feared its spillover effect on Kashmir. New Delhi thinks herself a victim of Islamic militancy. Therefore, India is against the Taliban regime in Afghanistan. On the other side, the Taliban's upper hand in Kabul favours Pakistan to pressure India for Kashmir (Taneja, 2017). India tried its best to support the Afghan military and train Afghan army officers in various army schools in New Dehli. Indian army officers also provided teaching facilities to female officials of the Afghan military, the primary army rules and fundamental English abilities (Ravi, 2017). New Delhi has trained Afghan army officials and did not think to deploy its foot soldiers in Kabul. India offered for a join drill of militaries in Dubai with the troops from Pakistan and NATO countries. It could not happen due to the trust gap between Pakistan and India. New Delhi is keen to spread its wings beyond the Central Asian region; New Delhi established a military base in Tajikistan back in 2007 with a worth of $10 \$$ million. Many other states like US, Germany and Russia also have their bases in Central Asia (Khattak, 2011).

Another side of the story gives a clear picture of New Dehli's impact in Kabul. The US is helping New Dehli to contain Beijing in the region of Southern Asia. The US is considering New Delhi as a strategic partner in South Asia. New Dehli is also ready to control South Asia and play its role in global politics. New Dehli always put effort to contain Islamabad in every segment, like security to the economy and politics to sports. Pakistan has not had friendly ties with Iran and Islamabad blamed Iran for interfering in 


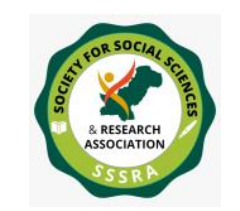

Pak. Journal of Int'L Affairs, Vol 4, Issue 4 (2021)

Indo- Afghan Relations: A Historical ...

Balochistan and other sectarian divides in Pakistan. This scuffle with Tehran and Islamabad facilitated New Delhi's interest in Kabul. Iran helps the Shia community in Afghanistan and supports Afghan refugees in Iran to enhance its impact in Afghanistan. Tehran, New Delhi, and Kabul put effort to increase trilateral ties via the port of Chabhar. New Delhi and Tehran have supported each other on commerce programs in Kabul; they aim to access Central Asia (Hameed, 2012). Ashgabat, Kabul, Islamabad, and New Delhi have inked a gas pipeline project. This project can solve the problems of energy in all these countries especially, Pakistan and India. TAPI was not a new idea; it was under discussion in the 90s during the regime of the Taliban. New Delhi became part of this program in 2008 (Bhutta, 2016). Peace and stability is the wish of every Afghan and people can only benefit from Indian projects if peace prevails. New Delhi has installed various projects on medical industries on a small scale and communication programs (Iwanek, 2019). Kabul has no direct access to the sea and Pakistani ports have been used for transportation by the Afghans.

After the event of September 11, Islamabad and Kabul never enjoyed friendly ties. Islamabad and Kabul have a lack of trust; both countries are blaming each other for supporting terrorism. New Delhi always took cashed this moment and used Afghan political leaders against Islamabad. New Delhi increased its commerce links with Afghanistan from 80 to 280 million dollars from 2001 to 2010. Afghanistan sells its $20 \%$ to India and New Delhi is the $5^{\text {th }}$ biggest seller in Kabul. The Indian regime also supported private firms to infuse money in Afghan markets. Hundreds of firms from India have infused money in various projects like the industry to agriculture, IT to power sector (Pasricha, 2012). New Delhi always tried to capture the minds of the Afghan youth and provided sports facilities to the youth of Afghanistan. India has participated in the global food initiative in Afghanistan. Students in schools were getting biscuits and other items from their institutions; its fundamental aim was to increase the number of students. University going youth of Afghans are getting scholarships from Indian institutions (Balachandar, 2012).

Indian media, especially its tv and film industry, is attracting local Afghans. People of Afghanistan are very much interested in the Indian Bollywood industry and sports industry. Media plays a significant role in public opinion in modern times, and countries are using media to increase their soft images. India has captured a larger part of the Afghan community through its media (Nooristani, 2013). New Delhi has friendly ties with the various factions of the Afghan community; now, things are changing speedily in Afghanistan. New Delhi did not enjoy the best ties with the Taliban. The Taliban now entered into cities, India must sit with the Taliban leadership to defend its projects. 


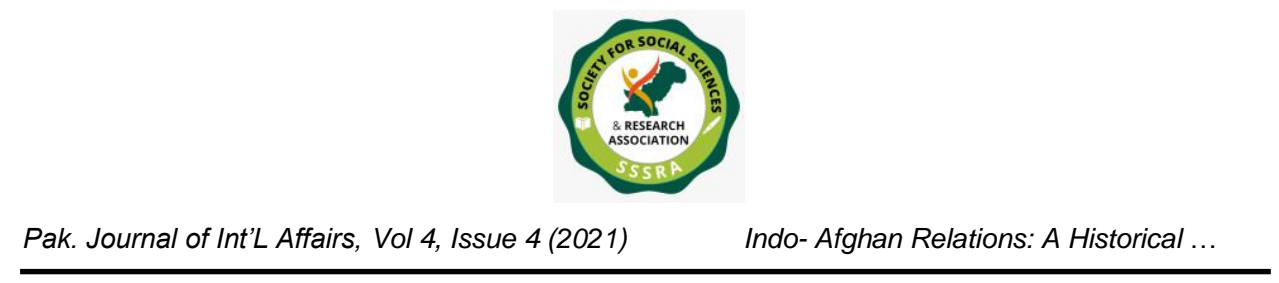

\section{Conclusion}

After 9/11, it was India's time in Afghanistan and has impacted the Afghan community after the demise of the Taliban government. New Delhi has been using Afghan territory to create disturbance inside Pakistan. Gawadar port and Chinese presence in Baluchistan is a point of great concern for India. India always supported anti-Taliban powers in Afghanistan. The Taliban's regime in Afghanistan is an excellent challenge for India. India wants to protect its investment in Afghanistan. Indian goals to create chaos inside Pakistan from Afghanistan's territory to create destabilization, but it will not be easy for New Delhi to execute its plans during the Taliban times. Peace and stability in Afghanistan do not suit India. The US has already stressed to New Delhi to talk with Taliban leaders to discuss future programs. It is not easy for New Delhi to speak with the Taliban. India has started to back-channel talks with the Taliban to set up a future roadmap. Pakistan has already made it clear that Afghan soil must not use against Islamabad. Things will clear in the coming days or months, but it's testing time for India and how it manages its ties with the Taliban. 


\section{References}

Ahmed, Z. S., \& Bhatnagar, S. (2015, June). Conflict or Cooperation? The Role of India and Pakistan in Post-2014 Afghanistan. South Asian Studies, 30(1), 259-276.

Awan, F. A., Alvi, A. S., \& Munir, R. (2019). Delhi-Kabul Nexus: Regional Dynamics and Geopolitical Perspective ( With Reference to Pakistan). Journal of Indian Studies, 5(1), 91-101. Retrieved October 2020

Balachandar, S. (2012, 30 November). India's Role in Afghanistan: Past Relations and Future Prospects. Retrieved March 2020, from Foreign policy Journal: https://www.foreignpolicyjournal.com/2012/11/30/indias-role-in-afghanistanpast-relations-and-future-prospects/

Bhutta, Z. (2016, March 4). Four countries ink deal for $\$ 10$ billion TAPI gas pipeline project. Retrieved March 2020, from The Express Tribune:

https://tribune.com.pk/story/1058949/tapi-gas-pipeline-four-countries-ink-dealfor-10-billion-project/

Choi, C. (2014, September 4). \$1 Trillion Trove of Rare Minerals Revealed Under Afghanistan. Retrieved March 2020, from Live Science: https://www.livescience.com/47682-rare-earth-minerals-found-underafghanistan.html

Constantino, Z. (2020). The India-Pakistan Rivalry in Afghanistan. Washington: United States Institute of Peace. Retrieved from https://www.usip.org/publications/2020/01/india-pakistan-rivalry-afghanistan

D'Souza, S. M. (2014, March 28). India in Post Afghanistan: Challenges and Opportunities. Retrieved March 2020, from Asian Century Institute: https://asiancenturyinstitute.com/international/535-india-in-post-2014-afghanistan

Fair, C. C. (2014, January). Securing Indian Interests in Afghanistan Beyond 2014. Retrieved March 2020, from The National Bureau of Asian Research: https://www.nbr.org/publication/securing-indian-interests-in-afghanistan-beyond2014/ 
Grades Fixer. (2019, January 3). Relations between India and Afghanistan. Retrieved March 2020, from Grades Fixer: https://gradesfixer.com/free-essayexamples/relations-between-india-and-afghanistan/

Hameed, S. (2012, August 22). Prospects for Indian-Pakistani Cooperation in Afghanistan. Retrieved March 2020, from Center for Strategic \& International Studies: https://www.csis.org/analysis/prospects-indian-pakistani-cooperationafghanistan

Iwanek, K. (2019, January 8). 36 Things India Has Done for Afghanistan. Retrieved March 2020, from The Diplomat: https://thediplomat.com/2019/01/36-thingsindia-has-done-for-afghanistan/

Joshi, N. (2018). Indian Engagement with Afghanistan An Economic Perspective. Vivekananda International Institute. New Dehli: Vivekananda International Foundation.

Kamal, M. (2019). Indian Strategic Influence in Afghanistan: Realists Ends through Social Means. A Research Journal of South Asian Studies, 34(2), 451-472. Retrieved October 2020

Kaul, A. (2007, June 10). Taliban menace: 134 Indian commandos to go to Afghanistan. Retrieved March 2020, from India Rediff Abroad: https://www.rediff.com/news/2007/jun/10afghan.htm

Kaur, B. (2017, February 21). India - Afghanistan: An Analysis of Strategic and Security Concerns. Retrieved March 2020, from Mainstream Weekly: http://www.mainstreamweekly.net/article6978.html

Khalid, D. I. (2011). The Great New Game In Afghanistan: Role of India (A Pakistani Perspective). Research Journal of South Asian Studies, 26(2), 241-257. Retrieved October 2020

Khattak, M.-U.-R. (2011, April 13). India's Presence In Afghanistan: Implications For Pakistan - Analysis. Retrieved March 2020, from Eurasia Review News \& Analysis: https://www.eurasiareview.com/13042011-indias-presence-inafghanistan-implications-for-pakistan-analysis/ 


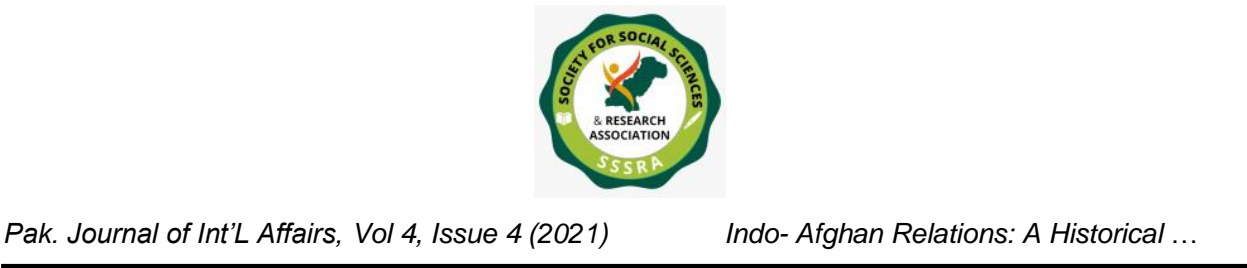

Mustafa, D. G., Junaid, A., Khan, R. B., \& Wakil, I. (2020). India's Role in Afghan Peace Process. Journal of Political Studies, 27(2), 129-140.

Nooristani, H. (2013, April 11). The Bollywood Effect: Women and Film in South Asia. Retrieved March 2020, from Foreign Policy: https://www.foreignpolicyjournal.com/2012/11/30/indias-role-in-afghanistanpast-relations-and-future-prospects/

Paliwal, A. (2015). India's Taliban Dilemma: To Contain or to Engage? The Journal of Strategic Studies, 40 (1-2), 35-67. Retrieved October 2020

Pande, A. (2020). India Could Emerge as the Global Power the World Has Been Waiting for After COVID. Retrieved October 2020, from Hudson Institute: https://www.hudson.org/research/16111-india-could-emerge-as-the-global-powerthe-world-has-been-waiting-for-after-covid

Pant, H. V. (2010, June 23). India in Afghanistan is a test case for a rising power. Contemporary South Asia, 18(2), 133-153.

Pasricha, A. (2012, June 28). India Presses for More Private Investment in Afghanistan. Retrieved March 2020, from Voice Of America: https://www.voanews.com/eastasia-pacific/india-presses-more-private-investment-afghanistan

Price, G. (2013, August). India's policy towards Afghanistan. Retrieved March 2020, from Chatham House: https://www.chathamhouse.org/sites/default/files/public/Research/Asia/0813pp_in diaafghanistan.

Ravi, A. P. (2017, December 6). In A First, Indian Army To Train Afghan Women Military Personnel. Retrieved March 2020, from NDTV: https://www.ndtv.com/india-news/in-a-first-indian-army-to-train-afghan-womenmilitary-personnel-1784238

Rehman, A. u. (2014). Peace Talks with Taliban: Expectations, Realities and Way. A Research Journal of South Asian Studies, 29(1), 197-205.

Saleem, M. (2018). Insurgency in Balochistan. Center for Strategic and Contemporary Research, 2(2), 1-16. 
Shah, F. (2017, February 23). Does the China-Pakistan economic corridor worry India? Retrieved October 2020, from Aljazeera: https://www.aljazeera.com/features/2017/02/23/does-the-china-pakistaneconomic-corridor-worry-india/

Siddiqui, S. (2017, October 12). India's Connect Central Asia Policy. Retrieved March 2020, from China.Org.Cn: http://www.china.org.cn/opinion/201710/12/content_41721919.htm

Souza, S. D., \& Jetly, R. (2012). Perspective On South Asian Security. Singapore: World Scientific Publishing Company.

Taneja, K. (2017, November 30). India and the Afghan Taliban Can Delhi contribute to an Afghan political reconciliation? Retrieved March 2020, from The Diplomat: https://thediplomat.com/2017/11/india-and-the-afghan-taliban/

The Hindu. (2013, February 27). India crucial for economic future of Afghanistan. Retrieved March 2020, from The Hindu: https://www.thehindubusinessline.com/news/world/india-crucial-for-economicfuture-of-afghanistan-robert-blake/article20584763.ece1

Tolo News. (2018, June 25). Afghanistan "Produces" $80 \%$ Of World's Opium. Retrieved March 2020, from Tolo News: https://tolonews.com/afghanistan/afghanistan$\%$ E2\%80\%9Cproduces\%E2\%80\%9D-80-world\%E2\%80\%99s-opium 